Publisher homepage: www.universepg.com, ISSN: 2663-7820 (Online) \& 2663-7812 (Print)

https://doi.org/10.34104/cjbis.019.01016

Canadian Journal of Business and Information Studies

Journal homepage: www.universepg.com/journal/cjbis

\title{
Customers' Satisfaction of Service Quality: A Study on the Customers of DBBL at Different Areas of Mymensingh District
}

\author{
Mohammad Toriqul Islam Jony ${ }^{1}$, Md. Jahangir Alam ${ }^{1}$, and Md. Shohel Rana ${ }^{2}$ \\ ${ }^{1}$ Dept. of Management, Jatiya Kabi Kazi Nazrul Islam University, Trishal, Mymensingh, Bangladesh; and ${ }^{2}$ Dept. of Human \\ Resource Management, Jatiya Kabi Kazi Nazrul Islam University, Trishal, Mymensingh, Bangladesh. \\ *Correspondence: jony.jkkniu@gmail.com
}

\begin{abstract}
This study is conducted to measure the level of customer satisfaction and understand the customer perceptions towards the bank regarding different service quality dimensions at different areas of the Mymensingh area. The study was carried out through a field survey among 300 customers of different branches of this bank at Mymensingh district. A well designed structured questionnaire including both open-ended and close-ended was developed by the researchers and randomly administered to the respondents to collect data. The study finds that customers of this bank are satisfied with the branch accuracy, less complexity in opening an account, security, behavior of employees, technology, and environment etc. The factors that contribute to customer's frustration are that they take too much time for the delivery of the cheque book and the interest rate for the loan is high; just as the bank does not provide loans without a mortgage.
\end{abstract}

Keywords: DBBL, Customer satisfaction, Mymensingh district, Competitive business, Mortgage, and Service.

\section{INTRODUCTION:}

In today's contemporary and highly competitive business world; it is disastrous for an organization not to be customer centered. Indeed, Organization will have to produce product and outstanding services to survive in the current competitive business world and it will result in happy and trusted customers (Fecikova, 2004). However Customer satisfaction is indispensable for the successful functioning of the company; it is now a day's anticipated as a foundation for the standard of performance and excellence for any business organization. To make sure the satisfaction of the customers, organizations must have to give a focus in meeting their hopes and aspirations (Amoake, 2010). If they can be doing well or fruitfully can point out the needs of their targeted customers, they can better fulfill the needs and wants

UniversePG I www.universepg.com of the customers. Therefore a company can achieve its goal very conveniently.

Companies of today's think that customer satisfaction is their main indicator of employee's performance and it will work as a strong base in creating a long term relationship with the customer (Islam and Alam, 2019). If a company can make certain of its customer is satisfied, they will work as a permanent advertisement and good will of the company. Hence, they will re-purchase it and influence others to purchase it. As a consequence, Companies are putting their supreme effort to satisfy their customer up to the highest level. But keeping the customer satisfied and maintaining a long term relationship with the customer is very challenging. It takes continuous effort to maintain high customer satisfaction levels. As today's markets are customer driven market and mostly controlled by customer. 
Companies are failing to improve customer satisfaction and maintaining their current customers happy to them. Therefore; they are trying to put in an offer of new and innovative goods and technologies according to the customer's demand because customers are well informed now. The purchasing decision of the customers is closely linked with their thorough analysis of the products and services. They are confident enough and switch to that brand from which they get more benefits. If customers became aware of the fact that they are getting some supplementary benefits from their relationship with employees, their satisfaction level with the company will enlarge (Beatty et al., 1996). Accordingly company of today's are becoming prudent and watchful to make their customers satisfied for the successful survival and smooth functioning of the business.

Bangladesh's banking industry is encountering severe competition day by day; new banks are accessing into the market and new technologies are generating for making it trouble free to the customers. In addition to it; the banks are continuously trying to put on innovative products in the product line and make their services better organized. However Dutch-Bangla Bank Limited (DBBL) is one of the established commercial banks of Bangladesh. The bank has begun its journey on June 3; 1996. The bank always tries to give the first concern to their customer's demands and focuses on customers' satisfaction. DBBL has persistently made a lot of contribution in the CSR activities and now they are one of the biggest significant donors in Bangladesh. Notwithstanding their target areas of CSR are education, health, disaster relief, sports, social awareness and social development. Anyway; the main goal of this report was to identify the customers' satisfaction regarding the services of DBBL.

\section{Literature Review:}

Anderso et al. (1997) conducted a study on customer satisfaction, productivity and profitability and they had measured the links between customer satisfaction and productivity. The results of the study confirmed that both of them were positively connected with ROI for goods and services, they found a positive relation between them in case of goods whereas it is comparatively low in services.

Ashaduzzaman et al. (2012) in their study tried to seek and measure the level of customer satisfaction and services rendered in the private commercial banks of Bangladesh. They conducted a survey on the customers of the different private commercial bank of different areas of the country and identified that the customers were fairly satisfied regarding the service they received from the private commercial banks of the country.

Cengiz, (2010) conducted a study and an investigation was made to find the answer of some questions which was developed by the researcher. The study found that customer constantly appraised the service of the company including the entire thing that affects the satisfaction of the customers.

Kashem \& Islam, (2012) they conducted a study on the superstores of different areas of Bangladesh to point out the influencing factors of customer's satisfaction and pinpointed the three factors comprised of products factor, store service factors, and customer facilities factors are noteworthy for customer satisfaction.

Masukuzzan \& Akter, (2010) they conducted a survey on the quality of services listed and customer's perception in connection to the satisfaction towards private commercial banks of Bangladesh with the motive to evaluate the quality of the service provided by the banks. The findings of the study affirmed that the quality of the service and customer loyalty of Islami Bank Bangladesh Limited is comparatively satisfactory than other private commercial banks.

Mazumder \& Hasan, (2014) they carried out a study on the national and international hotels of Bangladesh. The aim of this study was to highlight the differences between Bangladesh's national and international hotels based on expectation of the service and perceptions of customers towards the service provided by the hotels of the nation. The results divulged that the overall customer satisfaction levels towards the hotel stay is not satisfactory 
between domestic hotel guests and hotel guests from International countries.

Parasuraman et al. (1988) in their study sought to pinpoint which dimension affects in customer satisfaction and perception. After conducting a survey, they discovered five dimension namely, Reliability, Responsiveness, Assurance, Tangibility and Empathy dimension. These dimensions can serve as a tool to evaluate the satisfaction and perceptions of the customer.

Palto, (2010) carried out a study and made an inquiry in grocery food retailing in Bangladesh to identify the systems of marketing in creating customer relationship and customer retention. An investigation was made and the findings pointed out that customer retention had received appreciable attention and become a major factor for a food retail organization to increase the size, maximize profits, create and sustain a competitive food advantage.

Rahman \& Mukul, (2013) an investigation was made by the researchers to identify the influential factors of customer satisfaction of commercial banks of Bangladeshi. The findings affirmed that commercial banks had measured only those factors that are significant and needed to ensure customer satisfaction.

Thomas et al. (2010) the motive of this study was to evaluate the levels of customer satisfaction with services. The study's findings concluded that maximum numbers of customers were satisfied with service and they were positive towards specific aspects of service from different channels.

\section{Significance of the study:}

Customer satisfaction is inevitable in creating a long term relationship with the customers. But maintaining a long term relationship with them is quite a challenge and a difficult one. Only delivering superior value to the customers can make it possible.

As customers are regarded as the only king of the current global competitive business world if it can be assured properly. Any company will be successful in achieving the goals and objectives as well as maintain the long term profitable relationship with the customers.

\section{METHODOLOGY:}

The study had been conducted based on sources of both primary and secondary data.

Primary data - The data were obtained through faceto-face interview with a well designed structured questionnaire method from the randomly selected 300 customers of different branches of DBBL of Mymensingh district. The questionnaire was distributed to those customers who had taken any kind of services from this bank, whether they were the account holders of this bank or not.

The five-point Likert-type scale was also used in the study where $5=$ Excellent and $1=$ Very poor.

Secondary data - The banks related information were gathered from annual reports, numerous magazines, articles, web pages, and other published documents.

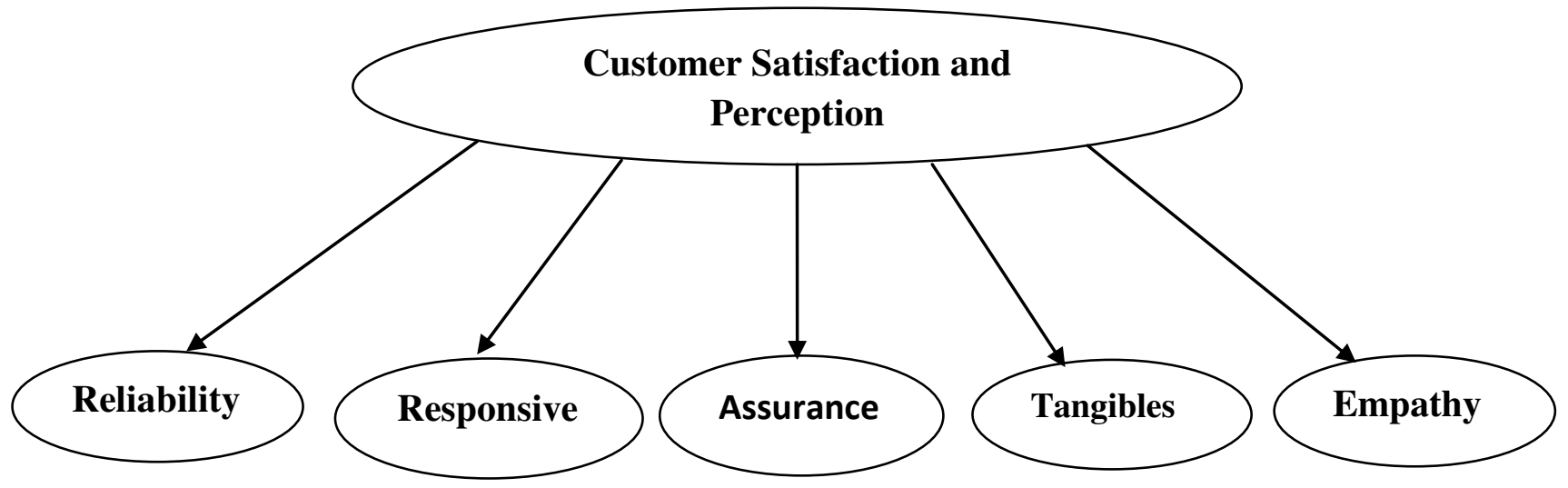

Fig 1: Theoretical framework of the study. 


\section{Theoretical framework of the study:}

This study is aimed at exploring the level of customer satisfaction (Based on the SERVQUAL Instrument identified by Parasuraman et al. (1985) on service quality among the customers of DBBL in different areas of Mymensingh.

\section{RESULTS AND DISCUSSION:}

The study deals with the measurement of the degree of satisfaction of the customers of DBBL based on several dimensions including reliability, responsiveness, assurance, tangibles, empathy, and other customer satisfaction dimension. We prepared a questionnaire for the analysis. The analysis is as follows.

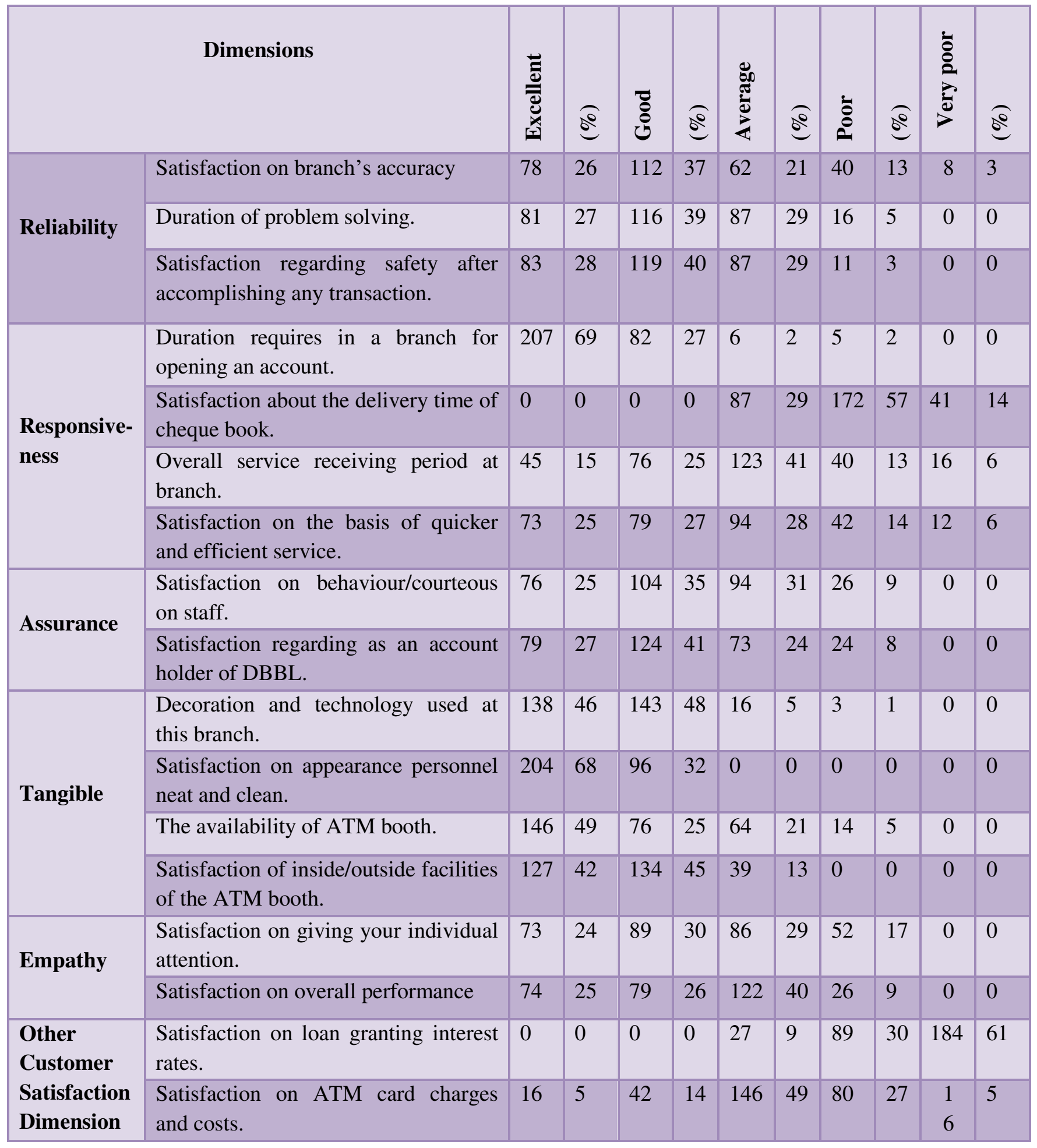




\section{FINDINGS OF THE STUDY:}

Based on our analysis of the study; It had been observed that the degree of satisfaction among account holder of appears to have been satisfactory. The customer-employee relations are also high which leads to customer satisfaction positively. The findings of the study are -

Customers are satisfied about the accuracy of the transactions.

* To open an account, the bank takes a very short time.

* Throughout their transaction with this bank, Customers also feel much secured.

- The time taken for the delivery of the cheque books is quite high compared to other private commercial banks.

* The action of employees enhances and stimulates confidence in customers.

\# The bank has state-of-the-art facilities.

* The outlook of the bank seems to be neat and clean.

* The bank employee pays individual attention the customers.

* The account holders have been well pleased on the overall performance of the bank.

The bank is not providing any loans to the customers without any mortgage as well as the interest rates are relatively high.

\section{Recommendation of the Study:}

$>$ Employee training and seminars should be conducted to offer them expertise and professionalism in customer interactions. With more professional base employees can better satisfy the customers. They should be taught about how to handle difficult customers and how to manage the problematic situations.

$>$ Customers showed dissatisfaction with the availability of ATM booths. New ATM booths in Dhaka city should be installed in diverse geographic segments. As very important factor customers is the ease of access to the branch location. In Dhaka City as well as other metropolitan cities in
Bangladesh, the bank should consider in building more ATM booths.

$>$ The bank should be more flexible enough in case of cheque book /delivery. Because the majority of customers were found to be very unhappy with the total time taken to deliver the cheque book.

$>$ The bank should upgrade the machines on ATM booths. Most clients come to inquire about issues with ATM booth. So they should give more concern on ATM booths problems like fund unavailability, network problem, power failure and solve these sought of problems as soon as possible.

$>$ The authority should reduce the amount of time required to provide the security items to the customers for whom it gets inconvenient for the customers, which leads to higher disappointment. Currently, it takes 1 week while some competitors can provide the card within 2 working days. The concerned authority should also make necessary arrangements to deliver the security items to customers on time to lower the customer difficulties faced in the absence of security items like cheque, ATM cards and etc.

$>$ The customers should be given more individual attention because customers think that they don't get enough individual attention.

$>$ The authority should reduce loan granting interest rate because the interest rate high. Most of the respondents show their dissatisfaction on interest rate.

By considering the above recommendations; the bank can enhance their quality of the service and satisfy their customers effectively and efficiency and keep them loyal to the company.

\section{CONCLUSION:}

This study is an attempt to reflect a clear idea about the understanding \& satisfaction of DBBL service quality. The results of this study pointed out that customers of these banks are happy with accuracy, environment, security, low complexity, care and the 
state-of-the art facilities etc. Besides it had been observed customers are well pleased about the overall performance of the bank which supports the findings of (Ashaduzzaman et al., 2011; Thomas et al., 2010).

It was also being noticed that when choosing among the different types of schemes; quality is being taken into the first priority according to the customer perception. It was pointed out; however, a few of the customers were disappointed with the quality of the service of the bank. To make these customers satisfied, some attempts can be taken by the management. If it's possible for the bank management to provide recommended services (E.g. reducing interest rate etc). The customer's perception regarding the quality of service the bank will be positive and the bank can establish itself as one of the most prominent bank in Bangladesh.

\section{Implications of the study:}

The findings of this study will provide the researchers with a new insight as some work is being done in Bangladesh in this area. It will also help job holders to be aware of their jobs and the associated factors of satisfaction and dissatisfaction. The research will also draw employers/decision makers attention to the factors which affects customer satisfaction.

\section{Suggestions for further research:}

Much of the research work in Bangladesh hasn't been conducted on that field, so definitely it will create a new opportunity for future researchers. The sample size should be more than the present study to get maximum accuracy of result;

- Adequate time should be allowed to prepare and administer the questionnaire;

- Data should be collected through active participation in the data collection process;

- The method of data collection should be more than one.

\section{ACKNOWLEDGEMENT:}

We would like to thank those who work on this topic of the research study to complete successfully.

\section{CONFLICTS OF INTEREST:}

The authors declared there are no conflict of interest to publish the present research study.

\section{REFERENCES:}

1. Amoake K. G. (2010). International Business Research, ISSN 1913-9004 (Print), ISSN 1913-9012.

2. Anderso E.W., Fornell C., and Rust R.T. (1997). Customer Satisfaction, Productivity, and Profitability: A study on Service and Goods. Journal of Michigan University, USA, 16(2), 129-145. https://doi.org/10.1287/mksc.16.2.129

3. Ashaduzzaman M. (2011). Impact Study of Environmental Factors on Sales Productivity in IDS Bangladesh Eastern University Journal, 3(2), 15-23.

4. Ashaduzzaman M., Khan M. M., and Farhana S. (2012). User Satisfaction Review of Private Commercial Banks in Bangladesh, South Asian J. of Commerce and Management, 2(3), 1-16.

5. Beatty, S. E., Mayer, M., Coleman, J. E., Reynolds, K. E., \& Lee, J. (1996). Customersales associate retail relationships. Journal of Retailing, 72(3), 223-247. https://doi.org/10.1016/S0022-4359(96)90028$\underline{7}$

6. Cengiz E. (2010). Measuring Customer Satisfaction- Must or Not, Journal of Naval Science and Engineering, 6(2), 76-88.

7. Dutch-Bangla Bank Limited annual report, 2018.

8. Fecikova, I. (2004). An index method for measurement of customer satisfaction. The TQM Magazine, 16(1), 57-66. https://doi.org/10.1108/09544780410511498

9. Islam MT., and Alam MJ. (2019). The Relationship between Informal Economy and GDP Growth: A Study on South-Asian Developing Countries. Can. J. Bus. Inf. Stud., 1(5), 01-09. https://doi.org/10.34104/\%20cjbis.019.0109

10. Kashem A. M., and Islam S. M. (2012). Customer Satisfaction of Super Stores in 
Bangladesh: An Explorative Study, Journal of Economics and Sustainable Development, 3(7), 24-30.

https://iiste.org/Journals/index.php/JEDS/article /view/2042

11. Masukuzzan M., and Akter A. (2010). Quality of Categorized Service and Customer Satisfaction in Banking Industry: An Empirical Study on Private Commercial Banks in Bangladesh, Journal of Business and Technology, 5(2), 19-37.

https://doi.org/10.3329/jbt.v5i2.9933

12. Mazumder S., and Hasan R. (2014). Measuring Service Quality and Customer Satisfaction of the Hotels in Bangladesh: A Study on National and International Hotel Guest, American Research Institute for Policy Development, 2(1), 95-111.

13. Palto R. D. (2010). An Examination into Customer Relationship Marketing and Customer Retention in Grocery food retailing in Bangladesh, International Trade \& Academic Research, 10(3), 67-93.

14. Parasuraman, A., Zeithaml, V.A., and Berry, LL. (1985). "A conceptual model of service quality and its implication", Journal of Marketing, 49: 41-50. https://doi.org/10.1177/002224298504900403

15. Parasuraman A., Zeithaml V. A., and Berry L. L. (1988). "SERVQUAL: a multi-item scale for measuring consumer perceptions of the service quality", Journal of Retailing, 64(1), 12-40.

16. Rahman A. M., and Mukul A.Z. (2013). Identifying the Factors of Customer Satisfaction in E-Banking System in the Context of Bangladesh, Global Journals Inc. (USA), 13(4), 1-8.

17. Thomas A., and Coleman N., et al. (2010). "Customer Satisfaction Research". ISBN: 978184712 775, 4, 1-143.

Citation: Jony MTI, Alam MJ, and Rana MS. (2019). Customers' satisfaction of service quality: a study on the customers of DBBL at different areas of Mymensingh district. Can. J. Bus. Inf. Stud., 1(5), 10-16. https://doi.org/10.34104/cjbis.019.01016 C) क्ञ 